УДК 378.4

DOI 10.18413/2712-7451-2020-39-2-227-237

\title{
Имидж-образующий контент личности учителя в современном образовательном пространстве
}

\author{
Коренецкая И.Н., Кузьмиченко А.А., Мацевич С.Ф. \\ Псковский государственный университет, \\ Россия, 180000, г. Псков, пл. Ленина, д. 2 \\ E-mail: irinallo@mail.ru, annakuzmichenko@gmail.com, s_matsevich@mail.ru
}

\begin{abstract}
Аннотация. В условиях расширения международного взаимодействия, роста числа участников программ академической мобильности особое значение имеет уровень иноязычной подготовки. Целью данного экспериментального исследования является определение контента и структуры имидж-образующих характеристик будущих учителей иностранного языка. В связи с этим возникает вопрос: какими личностными качествами должны обладать будущие учителя, которых мы готовим к работе в «школах будущего»? Мы изучили понятие «имидж»; исследовали структуру и функции имиджа учителя иностранного языка; провели анкетирование среди студентов направления «Педагогическое образование», профиль «Иностранные языки», а также среди учащихся 9-х и 10-х классов школ г. Пскова и их родителей с целью определения компонентов имиджа педагога, имеющих важное значение для них; на основе теоретикометодологической базы разработали методические рекомендации по формированию имиджа будущего учителя иностранного языка.
\end{abstract}

Ключевые слова: имидж учителя, структура имиджа, функции имиджа.

Для цитирования: Коренецкая И.Н., Кузьмиченко А.А., Мацевич С.Ф. 2020. Имидж-образующий контент личности учителя в современном образовательном пространстве. Вопросы журналистики, педагогики, языкознания, 39 (2): 227-237. DOI 10.18413/2712-7451-2020-39-2-227-237

\section{Image-making content of a teacher's personality in a modern educational space}

\author{
Irina N. Korenetskaya, Anna A. Kuzmichenko, Svetlana F. Matsevich \\ Pskov State University, \\ 2 Lenin Square, Pskov, 180000, Russia \\ E-mail: irinallo@mail.ru, annakuzmichenko@gmail.com, s_matsevich@mail.ru
}

\begin{abstract}
In the context of expanding international cooperation and an increase in the number of participants in academic mobility programs, the level of foreign language training is of particular importance. The purpose of this experimental study is to determine the content and structure of imagemaking characteristics for future teachers of a foreign language. In this regard, the question arises about the professionally, socially and personally effective teacher acting in the modern educational space. What personal qualities are necessary for future teachers who will work in "schools of the future"? To achieve the stated goal, we studied the concept of "image"; investigated the structure and functions of the image of a foreign language teacher; conducted a survey among students of the department of "Pedagogical Education", the specialization "Foreign Languages", as well as among pupils of the 9th and 10th grades of schools in the city of Pskov and their parents in order to determine the components of the image of the teacher that are important for them; on the basis of the theoretical and methodological base, we developed guidelines for forming the image of a future teacher of a foreign language.
\end{abstract}

Key words: image of a teacher, structure of an image, functions of an image. 
For citation: Korenetskaya I.N., Kuzmichenko A.A., Matsevich S.F. 2020. Image-making content of a teacher's personality in a modern educational space. Issues in Journalism, Education, Linguistics, 39 (2): 227-237 (in Russian). DOI 10.18413/2712-7451-2020-39-2-227-237

\section{Введение}

Вопрос о компонентах имиджа учителя иностранного языка в эпоху цифровизации звучит особенно остро. Различные иноязычные образовательные интернет-платформы, мобильные приложения по изучению иностранных языков, специальные программы на YouTube, видео ролики TikTok, программы академической мобильности лишают учителя его информационной исключительности, так как он перестает быть единственным источником информации. Совершенно новый взгляд на сферу образования представлен в «Атласе новых профессий» от Московской школы управления «Сколково», в котором обозначены новые направления подготовки специалиста в сфере образования: модератор, разработчик образовательных траекторий, тьютор, организатор проектного обучения, ментор стартапов, игромастер, игропедагог, тренер по майнд-фитнесу и др.

Ситуация вынужденного перехода на дистанционное обучение из-за пандемии коронавируса делает тему исследования особенно актуальной. Педагоги активно осваивают образовательные интернет-платформы Coursera, Skyeng, Открытое образование, интернетpeсурсы MIRO, Zoomconference и др. Образование будущего с новейшими интерактивными технологиями становится реальностью. Готовы ли будущие учителя стать «учителями будущего» и какими компетенциями необходимо для этого обладать?

А. Каспржак [2013] призывает к тому, чтобы в школу пришли другие, состоявшиеся люди, чтобы интересно было учить, а для этого школу нужно «распаковать», раскрыть...». Велик соблазн представить будущих учителей в школе будущего как «учителей 2.0», знающих в совершенстве о том, что такое Big Data, с легкостью управляющих «умным» пространством или даже предстающие в виде голограммы. Если обратиться к идеям духовного гуманизма Ш. Амонашвили [2018], то «новая школа» должна измеряться не зданиями и техникой. Новая школа - это, прежде всего, учитель. Учитель со своим сознанием, как будто из будущего пришёл и знает, как хорошо там, он берет детей и ведёт их туда.

В данном исследовании мы планируем определить имидж-образующий контент личности учителя, который бы способствовал тому, чтобы процесс обучения был мотивирующим и результативным. Имидж учителя, как утверждает Браун [Brown, 2007], относится к устойчивым характеристикам индивида и варьирует в зависимости от индивидуальных особенностей. Имидж учителя является важным фактором, определяющим результаты обучения [Eggen, Kauchak, 1996; Lightbown, Spada, 1999; Guangwei, 2004]. Анализ собственного имиджа позволит педагогу скорректировать те из своих характеристик, которые затрудняют взаимодействие с учащимися в образовательном пространстве [Medgyes, 1994; Puchta, Rinvolucri, 2005].

B разные исторические периоды педагог должен был соответствовать определенному набору требований, для этого составлялись профессиограммы, где отражались ключевые компетенции учителя. Общество создает стереотипы образа педагога, что влияет на восприятие представителя данной профессии. Под профессиональным имиджем мы понимаем образ человека, определяемый его профессиональными качествами. К таким характеристикам исследователи Л.К. Аверченко, Г.М. Залесов, Р.И. Мокшанцев, В.М. Николаенко [Психология управления, 1999] относят профессиональную компетентность; нравственную надежность; гуманитарную образованность (знания в сфере мировой культуры, общечеловеческих ценностей и т.д.); коммуникативную привлекательность; использование психологических техник. 
Целью настоящего исследования является определение структуры и содержательных компонентов имиджа современного учителя иностранного языка. Для реализации заявленной цели необходимо изучить понятие «имидж»; проанализировать структуру и функции имиджа учителя иностранного языка; разработать методические рекомендации по формированию имиджа учителя иностранного языка.

В научных исследованиях предметом научного интереса являются вопросы феномена имиджа в широком смысле [Шепель, 1994; Почепцов, 2001]; проявление имиджа на примере известных политических деятелей и прочих публичных личностей [Шепель, 1994]; психология личности и имиджа [Маркова, 1993; Перелыгина, 2002; Донская, 2004].

После выделения педагогической имиджелогии в отдельную отрасль активные исследования в этой сфере проводили А.А. Калюжный, В.А. Кан-Калик, Е.И. Пассов, В.Н. Черепанова, Е.А. Ямбург. В основном работы исследователей посвящены внешним проявлениям личности педагога, другие компоненты в аспекте формирования имиджа, к примеру, аксиологическая картина мира педагога, мультикультурность и др., изучены недостаточно. Индивидуальному стилю преподавания посвящены немногие работы [Evans et al., 2008].

\section{Объект и методы исследования}

Различные проявления имиджевых характеристик личности учителя предполагают использование целого ряда методов исследования. Проведенное исследование основывается на методах теоретического анализа отечественных и зарубежных литературных источников, контент-анализа видео-уроков, а также на диагностическом (анкетирование студентов, школьников, родителей), праксиометрическом методе и методе математической обработки результатов. Специфика объекта исследования обусловила применение интент-анализа, который позволяет выявить намерения субъекта на основе анализа его стиля общения и поведения. Изучение характеристик, определяющих имидж как позитивный, негативный или допустимый, предполагает использование метода сопоставительного анализа. Объект исследования включает в себя определение сущностных характеристик понятия «имидж», выявление специфики имиджа учителя иностранного языка, изучение функций имиджа учителя.

\section{Результаты и их обсуждение}

Для определения сущностных характеристик объекта исследования мы обратились к словарному значению понятия «имидж» в английском языке, из которого оно заимствовано. Понятие «имидж» полисемично и означает впечатление, которое человек производит на общество; «представление», «образ», который возникает в сознании при упоминании кого-либо или чего-либо; образ, но уже увиденный в зеркале, на фотографии, компьютере или по телевизору; слово или фраза, используемые в переносном значении с целью описать что-либо.

А.А. Калюжный [2004] определяет имидж как комплексное представление о человеке, которое складывается в результате полученных впечатлений от внешнего вида, поведения, менталитета и многих других факторов.

В.Н. Черепанова [2006] суммировала накопленный учеными опыт и вывела наиболее полную формулу имиджа в емком определении: «Индивидуальный имидж - это целенаправленно сформированный интегральный, целостный, динамичный феномен, обусловленный соответствием и взаимопроникновением внутренних и внешних индивидных, личностных и индивидуальных качеств субъекта, призванный обеспечить гармоничное взаимодействие субъекта с природой, социумом и самим собой». В.Н. Черепанова еще раз доказывает, что имидж - это совокупность внешних и внутренних характеристик личности, способный изменяться в силу развития личности. 
В зарубежных исследованиях [Беннетт, 1976; Хаймлих и Норланд, 1994; Кэмпбэлл и Крышевска, 1995; Грэша, 1996; Браун, 2001] понятие имидж рассматривается и как стиль преподавания. Общим для этих исследований является то, что имидж выступает как фактор, определяющий взаимодействие в образовательном пространстве. Каждый учитель обладает набором характеристик, которые делают его имидж уникальным.

В настоящее время в научном сообществе отношение к роли личности педагога в образовательном пространстве неоднозначно. С одной стороны, цифровизация и становление образования как сферы услуг требуют сформированности таких качеств, как системное мышление, клиентоориентированность, мультиязычность и мультикультурность, работа с людьми, работа в условиях неопределенности, управление проектами, навыки художественного творчества. Кроме того, об эффективности педагога свидетельствует уровень сформированности у него SOFT- и HARD-skills. C другой стороны, сторонники ноосферной педагогики ставят проблему перехода образования к новой парадигме, связанной с формированием нового человека, и необходимостью становления ноосферного образования в XXI веке как условия спасения человечества от экологической гибели через подъем качества человека, его разума, сознания, духовно-нравственных оснований [Василенко, 2008].

Очевидно, что с компонентами имиджа педагога, которые диктует сейчас цифровое общество, портфель навыков современного эффективного учителя будет неполным без антропологической и аксиологической составляющей ноосферной педагогики.

Профессия учителя иностранного языка имеет свою специфику. В связи с межпредметностью иностранного языка учитель должен иметь широкий кругозор. Он должен транслировать иноязычную культуру и при этом сохранять национальную идентичность. Мультиязычность и мультикультурность с межкультурной восприимчивостью - важные компоненты личности учителя иностранного языка. Учитель - это речевой партнер, умеющий создать комфортный для обучения микроклимат.

Профессиональный антураж, или набор предметов, которые окружают человека и в которых проявляется вкус и интересы человека, а также принадлежность к конкретному сообществу специалистов играет важную роль в формировании имиджа. К примеру, в кабинете иностранного языка должно быть необходимое для работы оборудование (магнитофон, компьютер, интерактивная доска, разные виды карт (для страноведения), флаги, сувениры).

Коммуникативные умения, иноязычная коммуникативная и профессиональнокоммуникативная компетенция являют основное отличие учителя иностранного языка от другого учителя-предметника.

Компоненты структуры имиджа учителя иностранного языка рассматривает А.А. Калюжный [Калюжный, 2004] и описывает четыре аспекта: внешний облик; вербальные и невербальные средства общения; внутреннее соответствие образа профессии или внутреннее «Я».

Существует иная, представленная в виде двух блоков, развернутая структура имиджа, которую предложила Л.Ю. Донская [Донская, 2004]. Природный компонент описывает базовые характеристики человека: пол, возраст, темперамент, если есть - физические несовершенства. Данный аспект имиджа практически не поддается корректировке.

Три группы личных качеств выделяет В.М. Шепель [Шепель, 1994]. В первую категорию попадают качества, которые позволяют нравиться людям: коммуникабельность, эмпатичность, рефлексивность, красноречивость. Вторую категорию образуют те качества, которые свидетельствуют о высоком уровне образования и воспитания личности: нравственные ценности, психическое здоровье, владение технологиями межличностного общения и упреждения конфликтов. Третья группа представлена качествами, свидетельствующими о жизненном и профессиональном опыте. 
Область применения имиджа широка, поэтому имидж будет выполнять разные функции. В общем смысле имидж обслуживает аксиологическую функцию и предполагает обмен ценностями между участниками коммуникации. Регулятивная функция контролирует социально-конкретные нормативно-ценностные представления и в то же время внешний вид и поведение в процессе общения. Функция самопрезентации создает имидж, а функция организации внимания позволяет отобрать те характеристики человека, которые оставят отпечаток и сохранятся в сознании окружающих людей. Функция привлечения и организации внимания обеспечивает запоминание созданного образа в массовом сознании через отбор наиболее выделяющихся характеристик субъекта. Помимо прочего имидж выполняет адаптивную функцию, которая позволяет субъекту сопоставить личные ожидания от общения с корпоративными требованиями. Функция социально-символического опознавания демонстрирует готовность человека к взаимодействию в обществе, идентификации коммуникативных партнеров и самоидентификации. Психологическая функция выполняет задачу создания психологического комфорта во время взаимодействия с другими людьми и повышения чувства собственной значимости. Коммуникативная функция отвечает за обмен информацией между собеседниками и ее доступность.

Личностно-возвышающая функция имиджа создает вокруг его обладателя ореол успешности, значимости, востребованности, стремления ему подражать [Симонова, 2014].

М.P. Варданян [Варданян, 2007] добавляет в список функций здоровьесберегающую функцию, утверждая, что негативный имидж педагога действует угнетающе и провоцирует быстрое утомление, нервные срывы и вспышки агрессии у учащихся.

Анализ теоретического материала по выявлению сущностного наполнения понятия «имидж» учителя в современном образовательном пространстве, определение критериев соответствия тому или иному уровню сформированности имиджевых характеристик, анализ функций имиджа в образовательном процессе позволяет сформулировать модель имидж-образующего контента личности учителя иностранного языка в современном образовательном пространстве (рис.1).

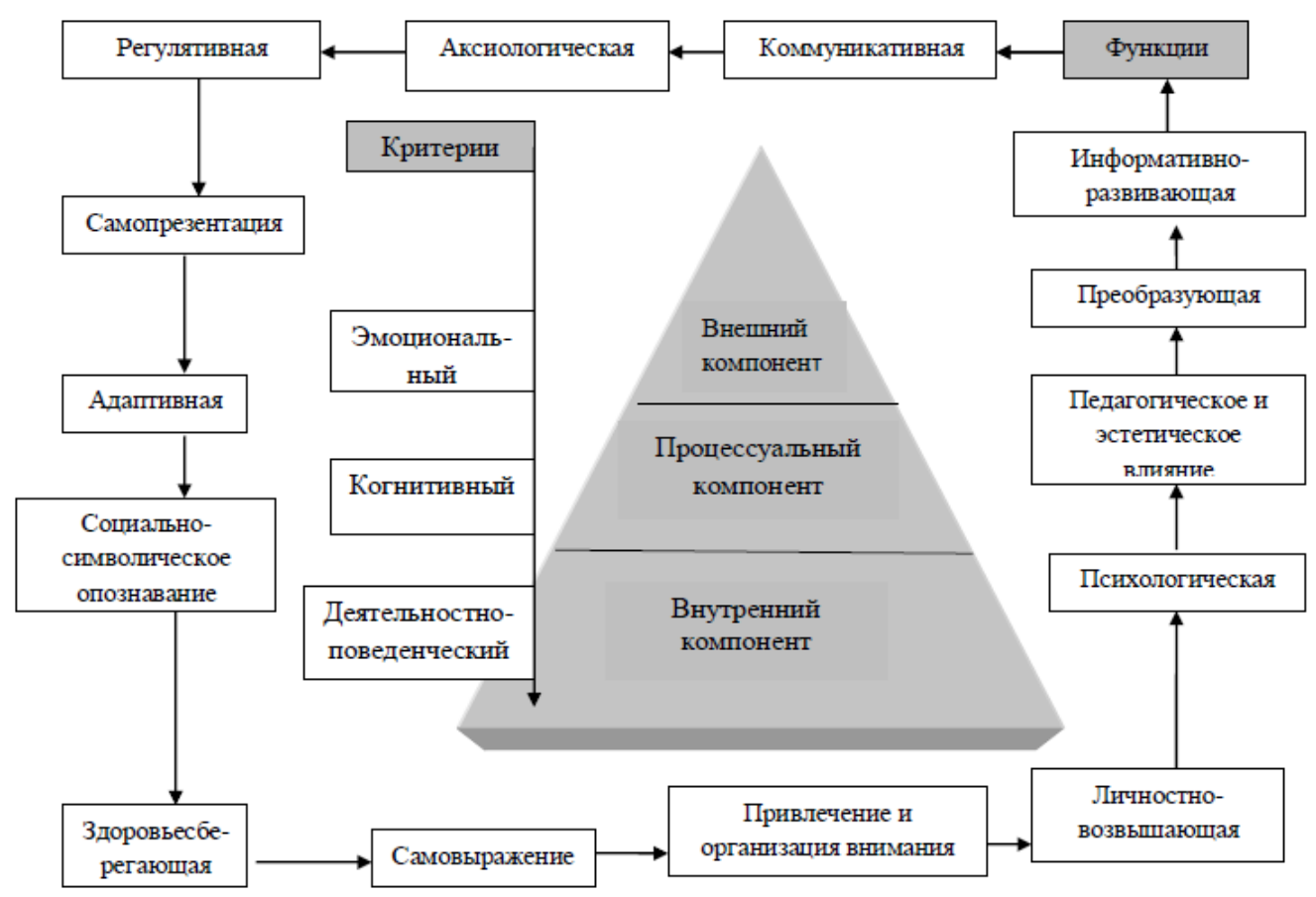

Рис.1. Модель имидж-образующего контента личности учителя в современном образовательном пространстве

Pic.1. Model of an image-making content of teacher's personality in modern educational space 
Внешний компонент имиджа - это внешние проявления, такие как деловой стиль в одежде, вербальные и невербальные (проксемика, окулистика, кинесика, сенсорика, хроматика и т.д.), паравербальные характеристики взаимодействия, оформление пространства вокруг себя. Это образ, или целостная картина, возникающая в сознании, когда мы видим и воспринимаем учителя, а также то, что остается в памяти после взаимодействия с педагогом. Внешние проявления - это манера поведения, походка, жесты, мимика, одежда, прическа и т.д.

Под внутренним компонентом мы подразумеваем набор психолого-педагогических качеств личности, ценностей, мировоззрение, межличностную и межкультурную восприимчивость и эмпатию, установки на понимание и диалог, мультиязычность, мультикультурность, SOFT и HARDskills. Внутренний аспект включает в себя интересы, эрудицию, творческий подход, хобби. Процессуальный аспект - это темперамент, эмоции, волевые качества. Всепронизывающим является ценностный аспект имиджа. Он определяется жизненной позицией человека, приоритетами, ценностными установками, а также созданной легендой. Профессиональная репутация педагога, к которой можно отнести наработанный практический и теоретический опыт, авторские методики, отзывы детей, родителей, коллег о профессиональной компетентности, профессиональные награды и премии, фото и видео свидетельства его деятельности, авторские сайты, публикации и т.д. Важно, чтобы имидж был цельным, когда его внешние проявления не расходятся с внутренними установками учителя, соответствуют его характеру и взглядам.

Можно выделить три базовых критерия сформированности имиджа личности: эмоциональный (степень готовности к самоосмыслению и к изменениям собственного имиджа), когнитивный (степень владения понятийным аппаратом по ключевым компонентам имиджа), деятельностно-поведенческий (степень реализации лучших проявлений собственного имиджа в образовательном пространстве).

В зависимости от степени проявления этих характеристик имидж учителя можно оценить как положительный (высокая степень сформированности характеристик), допустимый (средний уровень сформированности перечисленных характеристик), негативный (низкая степень сформированности характеристик).

Анализ результатов диагностики среди студентов направления «Педагогическое образование» (профиль «Иностранные языки») Псковского государственного университета (4 курс, 20 человек), проведенной после школьной педагогической практики осенью 2019 года (тест Сонди; многофакторное исследование личности по методике Кеттелла; опросник личностных ориентаций Шострома; тест эмоционального интеллекта EQ Холла), свидетельствует о том, что около 83 \% студентов имеют средний уровень сформированности компонентов имиджа, около 4 \% имеют негативный имидж, у 13 \% сформирован положительный имидж.

Негативный имидж у будущих педагогов проявляется во внешнем облике (недопустимые джинсы, вычурный макияж), стиле общения (две крайности: высокомернонадменный или очень робкий, тихий голос, эмоционально неокрашенный и монотонный), а также в когнитивной составляющей (две крайности: учитель не производит впечатление знающего, поэтому не вызывает авторитета, отсюда проблемы с дисциплиной у учащихся, или, учитель ведет урок полностью на английском, не снимая языковых трудностей для учащихся, в связи с этим материал урока не усваивается, учащиеся боятся высказать собственное мнение, так как оно может быть неверным с точки зрения педагога).

Кроме того, было разработано авторское анкетирование для учащихся 9-х и 10-х классов школ г. Пскова. Если проанализировать ответы учащихся, то идеальный учитель иностранного языка - женщина, одетая в нейтральной гамме повседневного или классиче- 
ского стиля (другой вариант - яркие цвета). Она эмоциональна, но в то же время держит дистанцию, не нарушая личное пространство своих учеников. Она коммуникабельна, любит детей и творчески подходит к своей профессии. Но профессионализм вообще не ставится учащимися во главу угла.

Анкетирование родителей выявляет другие компоненты имиджа учителя иностранного языка. Так, родители детей начальных классов хотели бы, чтобы учитель был добр и справедлив к их ребенку, чтобы, отправив ребенка в школу, родителям было спокойно. Кроме того, родителям важно, чтобы учитель был сильным предметником, и не было необходимости в репетиторах. Родители детей старших классов делают акцент на результат работы учителя: успешно сданный ЕГЭ. К учителю английского языка особые требования: ребенок должен заговорить по-английски, и это главный критерий работы учителя.

Существует еще и внешний фактор, влияющий на формирование имиджа учителя: социальное благополучие учителя, возможность повышать свою квалификацию, участвовать в программах академической мобильности за рубежом в странах изучаемого языка.

Далее мы проанализировали видеоуроки по английскому языку конкурсных испытаний Всероссийского конкурса «Учитель года России». Данные материалы доказывают непосредственную взаимосвязь влияния позитивного имиджа учителя (в совокупности всех его компонентов) на высокие результаты формирования иноязычной коммуникативной компетенции. Высокий уровень сформированности трех компонентов имиджа (внешний, внутренний, процессуальный) позволили учителям достичь поставленных задач на уроках. Безусловно, по-разному раскрывались и функции имиджа. Функция самопрезентации и привлечения внимания проявлялась в предпочтениях классического стиля в одежде, но с яркой деталью в облике (яркий платок на шее, красивая брошь, ассиметричная короткая стрижка). Коммуникативная функция имиджа находит выражение в создании доброжелательной атмосферы на уроке, организации условий для диалога и обмена мнениями на равных. Учителю удается создать позитивный микроклимат в классе, где есть место юмору, не только со стороны самого педагога, но и школьников. В этом также проявляется и здоровьесберегающая функция.

Анализ видеоуроков позволил убедиться, что имидж учителя иностранного языка воздействует на обучающихся комплексно, в совокупности всех его компонентов.

Результаты диагностики, которые показали, что 83 \% студентов имеют средний уровень сформированности компонентов имиджа, что свидетельствует о необходимости разработки специальной программы по формированию имиджа будущих учителей иностранного языка.

Реализация данной программы и освоение имидж-формирующего контента будущими учителями иностранного языка возможны в рамках дисциплины «Методика обучения иностранному языку», «Теория и практика межкультурной коммуникации», а также в рамках освоения основного курса «Иностранный язык», когда студенты направления «Педагогическое образование» наполняют «Портфель имидж-формирующего контента учителя иностранного языка» необходимыми характеристиками, а также оценивают свою сильные и слабые стороны, проектируют индивидуальные траектории собственного развития по формированию положительного имиджа.

Теоретический материал по проблеме педагогического имиджа позволяет сформулировать ряд рекомендаций, которыми можно руководствоваться при построении профессиональных траекторий формирования положительного имиджа будущего учителя иностранного языка: 
1) развивать компоненты имиджа по блокам. Рекомендуется начать трансформацию имиджа с внешнего блока. Внешние изменения повлекут за собой внутренние;

2) составить список внешних и внутренних качеств, которые необходимо развивать в имидже учителя иностранного языка;

3) уметь вести диалог, проявляя интерес и внимание к учащимся, понимать и принимать учащихся, извлекая смыслы из жизненных проявлений субъектов образовательного процесса и интерпретируя на основе собственного жизненного опыта, но с учетом ценностей понимаемого;

4) совершенствовать навыки рефлексивного и нерефлексивного слушания. Способность быть хорошим слушателем (не равнодушным и не формально выполняющим эту роль) гарантирует успех в коммуникации;

5) быть осведомленным по темам, интересным для учащихся;

6) интересоваться вопросами актерского мастерства, артистичности.

\section{Заключение}

Таким образом, авторами проанализировано понятие имидж, определены его функции и структура, выделены критерии уровней проявления имиджа. Экспериментальная работа позволила сформулировать ряд методических рекомендаций для формирования позитивного имиджа у будущих учителей иностранного языка.

Изучение вопросов, связанных с формированием положительного имиджа учителя является перспективным в связи с тем, что нерешенными остаются вопросы преодоления неудовлетворенности преподавателей собой, своим имиджем, несоответствия «образа Я» и «образа профессии»; соотношения механизмов межгруппового и межличностного восприятия в процессе общения; решающего воздействия первого впечатления на последующее сотрудничество; отсутствия или незначительного набора знаний о формировании и коррекции индивидуального имиджа; отсутствия эффективной обратной связи «учитель глазами учащихся» или рейтинг учителей, который формируют учащиеся; раскрытия механизмов положительного формирования и развития имиджа.

Имидж - это не константа, поэтому важно научить выпускников постоянной работе над ним. Каждый ученик - это новый опыт педагогического взаимодействия. Поэтому учитель учитсявместе с учениками, будучи в чем-то на шаг впереди.

Кроме того, интересным представляется рассмотрение в дальнейшем проблемы имиджа с позиций аксиологического подхода. Сейчас наблюдается изменение ценностей общества в сторону материального аспекта. Успешными и престижными считаются те профессии, которые позволяют человеку оказаться на верху социальной лестницы. Профессия учителя не престижна уже в глазах пятиклассника. С этим связаны и определенные риски в процессе обучения. Важно создать условия для становления не только успешного, но и счастливого профессионального имиджа учителя, чтобы он был притягательным для учащихся, и тем самым способствовал эффективному достижению целей обучения.

\section{Список источников}

1. Атлас новых профессий. 2020. URL: http://atlas100.ru/ (дата обращения: 10.02.2020).

2. Психология управления. 1999. Л.К. Аверченко, Г.М. Залесов, Р.И. Мокшанцев, В.М. Николаенко. Отв. ред. М.В. Удальцов. М., Новосибирск, ИНФРА-М, 149 с.

3. Черепанова В.Н. 2006. Введение в педагогическую имиджелогию. Под ред. Макарени А.А., Самойловой М.И. 194 с.

4. Шепель В.М. 1994. Имиджелогия: секреты личного обаяния. Москва, Культура и спорт, Юнити, 320 с. 


\section{Список литературы}

1. Амонашвили Ш.А. 2018. Основы гуманной педагогики. Книга 3. Школа жизни. М., Амрита-Русь, 320 с.

2. Василенко В.Н. 2008. Ноосферное сознание в поэтике поколений. К 145-летию В.И. Вернадского. Предисловие к монографии. В кн.: Дзюра А.И. Ноосферные предпосылки философии творчества. Вольные этюды. М., МАКС Пресс, с. 6.

3. Варданян М.Р. 2007. Имидж педагога как фактор здоровьесбережения субъектов образовательного процесса в основной школе. Автореф. дис. .... канд. пед. наук. Омск, 23 с.

4. Донская Л.Ю. 2004. Психологические условия формирования имиджа учителя высшей школы. Автореф. дис. ... канд. псих. наук. Ставрополь, 21 с.

5. Калюжный А.А. 2004. Психология формирования имиджа учителя. Москва, Владос, 224 с.

6. Кан-Калик В.А. 1987. Учителю о педагогическом общении. Москва, Просвещение, 190 с.

7. Капустина А.Н. 2004. Многофакторная личностная методика Р. Кеттелла. СПб., Речь, $104 \mathrm{c}$.

8. Каспржак А.Г. 2013. Институциональные тупики российской системы подготовки учителей. Вопросы образования, 4: 255-277.

9. Маркова А.К. 1993. Психология труда учителя. Москва, Просвещение, 192 с.

10. Пассов Е.И. 2001. Мастерство и личность учителя: на примере преподавания иностранного языка. Москва, Флинта, Наука, 240 с.

11. Почепцов Г.Г. 2001. Профессия: имиджмейкер. СПб., Алетейя, 256 с.

12. Симонова И.Ф. 2014. Формирование имиджа специалиста социально-культурной сферы в культурно-образовательном пространстве вуза. Дис. ... канд. пед. наук. Санкт-Петербург, 237 с.

13. Сомова С.В. 2015. Личность учителя иностранного языка. Современные проблемы науки и образования, 1 (2). URL: http://science-education.ru/ru/article/view?id=20192 (дата обращения: 25.02.2020).

14. Сонди Л. 2005. Учебник экспериментальной диагностики влечений. М., Когито-Центр, $557 \mathrm{c}$.

15. Фетискин Н.П., Козлов В.В., Мануйлов Г.М. 2009. Социально-психологическая диагностика развития личности и малых групп. М., Издательство Института Психотерапии, 362 с.

16. Шостром Э. 2008. Человек-манипулятор. Внутреннее путешествие от манипуляции к актуализации. Пер. Р. Римская, Н. Шевчук. М., Апрель-Пресс, 192 с.

17. Ямбург Е. 2007. Учитель - это стиль. Народное образование, 4: 175-179.

18. Bennet N. 1976. Teaching styles and pupil progress. Boston, Harvard University Press, 203 p.

19. Brown D. 2007. Principles of language learning and teaching. New York, Pearson-Longman, $347 \mathrm{p}$.

20. Campbell C., Kryszewska H. 1995. Towards teaching. Oxford, Heinemann, 86 p.

21. Eggen P., Kuachak D. 1996. Strategies for teachers. Teaching content and thinking skills. Boston, Allyn and Bacon, $346 \mathrm{p}$.

22. Evans C., Harkins M., Young F. 2008. Exploring teaching styles and cognitive styles: evidence from school teachers in Canada. North American Journal of Psychology: 567-582.

23. Grasha A. 1996. Teaching with style: a practical guide to enhancing learning by understanding teaching and learning styles. Pittsburgh, Alliance Publishers, $385 \mathrm{p}$.

24. Guangwei, H. U. 2004. Teaching and Learning a Second Language. A Guide to Recent Research and Its Applications. Asian Journal of English Language Teaching, 14: 151-156.

25. Heimlich J., Norland E. 1994. Teaching style: Where are we now? New directions for adult and continuing education, 93: 40-56.

26. Lightbown P., Spada N. 1999. How Languages are Learned. Oxford: Oxford University Press, $252 \mathrm{p}$.

27. Medgyes P. 1994. The non-native teachers. Bonn, Hueber, 114 p.

28. Puchta H., Rinvolucri M. 2005. Multiple intelligences in EFL exercises for secondary and adult students. Rome, Hebling languages, 158 p. 


\section{References}

1. Amonashvili Sh.A. 2018. Osnovy gumannoy pedagogiki. Kniga 3. Shkola zhizni [Fundamentals of humane pedagogy. Book 3. School of life]. M., Publ. Amrita-Rus', 320 p.

2. Vasilenko V.N. 2008. Noosfernoe soznanie v poetike pokoleniy. K 145-letiju V.I. Vernadskogo. Predislovie k monografii. [Noospheric consciousness in the poetics of generations. To the 145th anniversary of V.I. Vernadsky. Preface to the monograph.]. In: Dzyura A.I. Noosfernye predposylki filosofii tvorchestva. Vol'nye etyudy [Noospheric prerequisites for the philosophy of creativity. Free etudes]. M., Publ. MAKS Press: p. 6.

3. Vardanyan M.R. 2007. Imidzh pedagoga kak faktor zdorov'esberezheniya sub'ektov obrazovatel'nogo processa $\mathrm{v}$ osnovnoj shkole [The image of a teacher as a factor in the health conservation of subjects of the educational process in a primary school]. Abstract. dis... cand. ped. sciences. Omsk, 23 p.

4. Donskaya L.Yu. 2004. Psihologicheskie usloviya formirovaniya imidzha uchitelya vysshej shkoly [Psychological conditions for the image of a higher education teacher]. Abstract. dis. ... cand. psych. sciences. Stavropol, $21 \mathrm{p}$.

5. Kalyuzhnyj A.A. 2004. Psihologiya formirovaniya imidzha uchitelya [Psychology of teacher image formation]. Moscow, Publ. Vlados, $224 \mathrm{p}$.

6. Kan-Kalik V.A. 1987. Uchitelyu o pedagogicheskom obshchenii [To a teacher about pedagogical communication]. Moscow, Publ. Prosveshchenie, 190 p.

7. Kapustina A.N. 2004. Mnogofaktornaya lichnostnaya metodika R. Kettella [R. Kettell's multifactor personal technique]. Saint Petersburg, Publ. Rech, 104 p.

8. Kasprzhak A.G. 2013. Institutsional'nye tupiki rossiyskoy sistemy podgotovki uchiteley [Institutional dead ends of the Russian teacher training system]. Voprosy obrazovaniya, 4: 255-277.

9. Markova A.K. 1993. Psihologiya truda uchitelya [The psychology of the teacher's work]. Moscow, Publ. Prosveshchenie, 192 p.

10. Passov E.I. 2001.Masterstvo i lichnost' uchitelya: Na primere prepodavaniya inostrannogo yazyka [Mastery and personality of the teacher: the example of teaching a foreign language]. Moscow, Pybl. Flinta, Nauka, 240 p.

11. Pochepcov G.G. 2001. Professiya: imidzhmejker. [Profession: Image Maker]. S.-Petersburg, Publ. Aletejya, $256 \mathrm{p}$.

12. Simonova I. F. 2014. Formirovanie imidzha spetsialista sotsial'no-kul'turnoy sfery v kul'turnoobrazovatel'nom prostranstve vuza [Formation of the image of a specialist in the socio-cultural sphere in the cultural and educational space of the University]. Abstract. dis. ... cand. ped. sciences. SanktPeterburg, $237 \mathrm{p}$.

13. Somova S.V. 2015. Lichnost' uchitelya inostrannogo yazyka [The identity of a foreign language teacher]. Sovremennye problemy nauki i obrazovaniya, 1 (2). Available at: http://scienceeducation.ru/ru/article/view?id=20192 (accessed: 25.02.2020).

14. Sondi L. 2005. Uchebnik eksperimental'noj diagnostiki vlechenij [Textbook of experimental diagnostics of attractions]. Moscow, Publ. Kogito-Centr, 557 p.

15. Fetiskin N.P., Kozlov V.V., Manuylov G.M. 2009. Sotsial'no-psikhologicheskaya diagnostika razvitiya lichnosti i malykh grupp [Socio-psychological diagnostics of the development of individuals and small groups]. M., Publ. Instituta Psikhoterapii, 362 p.

16. Shostrom E. 2008. Chelovek-manipulyator. Vnutrennee puteshestvie ot manipulyatsii k aktualizatsii [Human manipulator. Publ. The inner journey from manipulation to actualization]. Per. R. Rimskaya, N. Shevchuk. M., Publ. Aprel'-Press, 192 p.

17. Yamburg E. 2007. Uchitel' - eto stil' [The teacher is a style]. Narodnoe obrazovanie, 4: $175-179$.

18. Bennet N. 1976. Teaching styles and pupil progress. Boston, Harvard University Press, 203 p.

19. Brown D. 2007. Principles of language learning and teaching. New York, Pearson-Longman, $347 \mathrm{p}$.

20. Campbell C., Kryszewska H. 1995. Towards teaching. Oxford, Heinemann, 86 p.

21. Eggen P., Kuachak D. 1996. Strategies for teachers. Teaching content and thinking skills. Boston, Allyn and Bacon, 346 p. 
22. Evans C., Harkins M., Young F. 2008. Exploring teaching styles and cognitive styles: evidence from school teachers in Canada. North American Journal of Psychology: 567-582.

23. Grasha A. 1996. Teaching with style: a practical guide to enhancing learning by understanding teaching and learning styles. Pittsburgh, Alliance Publishers, 385 p.

24. Guangwei, H.U. 2004. Teaching and Learning a Second Language. A Guide to Recent Research and Its Applications. Asian Journal of English Language Teaching, 14: 151-156.

25. Heimlich J., Norland E. 1994. Teaching style: Where are we now? New directions for adult and continuing education, 93: 40-56.

26. Lightbown P., Spada N. 1999. How Languages are Learned. Oxford: Oxford University Press, $252 \mathrm{p}$.

27. Medgyes P. 1994. The non-native teachers. Bonn, Hueber, 114 p.

28. Puchta H., Rinvolucri M. 2005. Multiple intelligences in EFL exercises for secondary and adult students. Rome, Hebling languages, 158 p.

\section{ИНФОРМАЦИЯ ОБ АВТОРАХ}

Коренецкая Ирина Николаевна, кандидат педагогических наук, доцент кафедры иностранных языков для нелингвистических направлений факультета русской филологии и иностранных языков института гуманитарных наук и языковых коммуникаций Псковского государственного университета, г. Псков, Россия

Кузьмиченко Анна Александровна, старший преподаватель кафедры иностранных языков для нелингвистических направлений факультета русской филологии и иностранных языков института гуманитарных наук и языковых коммуникаций Псковского государственного университета, г. Псков, Россия

Мацевич Светлана Фёдоровна, кандидат педагогических наук, доцент кафедры иностранных языков для нелингвистических направлений факультета русской филологии и иностранных языков института гуманитарных наук и языковых коммуникаций Псковского государственного университета, г. Псков, Россия

\section{INFORMATION ABOUT THE AUTHORS}

Irina N. Korenetskaya, Candidate of Pedagogical Sciences, Associate Professor of the Department of Foreign Languages for Non-Linguistic Studies at the Faculty of Russian Philology and Foreign Languages, Institute of Humanities and Language Communications, Pskov State University, Pskov, Russia

Anna A. Kuzmichenko, Senior Lecturer of the Department of Foreign Languages for NonLinguistic Studies at the Faculty of Russian Philology and Foreign Languages, Institute of Humanities and Language Communications, Pskov State University, Pskov, Russia

Svetlana F. Matsevich, Candidate of Pedagogical Sciences, Associate Professor, Department of Foreign Languages for Non-Linguistic Studies, Faculty of Russian Philology and Foreign Languages, Institute of Humanities and Language Communications, Pskov State University, Pskov, Russia 